\title{
Seroepidemiological Markers of Enterically Transmitted Viral Hepatitis $A$ and $E$ in Individuals Living in a Community Located in the North Area of Rio de Janeiro, RJ, Brazil
}

\author{
Damião Carlos Moraes dos Santos ${ }^{+}$, Francisco José Dutra Souto*, \\ Débora Regina Lopes dos Santos, Cláudia Lamarca Vitral/**, Ana Maria Coimbra Gaspar
}

Departamento de Virologia, Instituto Oswaldo Cruz-Fiocruz, Av. Brasil 4365, 21045-900 Rio de Janeiro, RJ, Brasil *Fundação Universidade Federal do Mato Grosso, 78060-900 Cuiabá, MT, Brasil **Universidade Federal Fluminense, Niterói, RJ, Brasil

We investigated the seroprevalence of hepatitis A virus (HAV) and hepatitis E virus (HEV) infection in subjects living in the community of Manguinhos, Rio de Janeiro, Brazil, and assisted at the Health Unit of Escola Nacional de Saúde Pública, Fundação Oswaldo Cruz. After formal consent, individuals were submitted to an interview using a standardized questionnaire. Anti-HAV and anti-HEV antibodies were detected by ELISA. Statistical analysis was carried out using the Epi-Info 6.04b software, to investigate possible associations between serological markers and risk factors. Results were regarded as significant when $p$ value $<0.05$.

Although a high prevalence of anti-HAV was observed (87\%), almost 50\% of subjects under the age of 10 were susceptible to HAV infection, an unexpected rate in endemic areas. This fact could be attributed to improvements in environmental sanitation, occurring in this area in the last years. The increasing proportion of susceptible people may result in outbreaks of HAV infection, since the virus still circulates in this area, as verified by the detection of anti-HAV IgM in some individuals. No statistical association was met between HAV infection and the risk factors here assessed. The anti-HEV IgG prevalence found in this population was $2.4 \%$, consistent with the one found in non-endemic areas.

Key words: hepatitis A virus - hepatitis E virus - seroprevalence - epidemiology - Rio de Janeiro - Brazil

Viral hepatitis is a public health problem worldwide. Two of the agents that cause viral hepatitis are enterically transmitted: hepatitis A virus (HAV) and hepatitis E virus (HEV).

In the last years, improvements in environmental sanitation and hygienic conditions, such as piped water and sewage system, have been responsible for a decrease in the endemicity level of hepatitis A in several developing countries. In Brazil, although hepatitis A is considered an endemic disease (Pannuti et al. 1985, Abuzwaida et al. 1987, Bensabath et al. 1987, Queiroz et al. 1995), data published in recent investigations carried out in the State of Rio de Janeiro revealed a shift in the hepatitis A epidemiological pattern. Improvements in life standards of some urban populations are responsible for a decrease in antibody prevalence among children and adolescents (Vitral et al. 1998a,b).

$\mathrm{HEV}$ infection is quite common in some geographic areas like India, Africa and Southeast Asia, where it can represent the main cause of acute hepatitis (Arankalle et al. 1995). Major epidemic outbreaks of HEV have been

This paper received financial support from $\mathrm{CNPq} / \mathrm{IOC}$. ${ }^{+}$Corresponding author. Fax: +55-21-2270.6397. E-mail: dcmoraes@zipmail.com.br

Received 29 October 2001

Accepted 27 March 2002 reported in these areas (Shakhgildyan et al. 1986, CDC 1987, Belyakov et al. 1990, Zuang 1992). On the other hand, epidemiological investigations in non-endemic areas show a low, but constant presence of anti-HEV antibodies (about 1.2\%) in normal human populations (Balayan et al. 1996, Psichogiou et al. 1996, Irshad 1999).

In 1986, the occurrence of outbreaks of HEV infection in the Americas was recognized in Mexico (Velazquez et al. 1990). More recently, two acute cases of hepatitis E were described in Argentina (Schlauder et al. 2000). In Brazil, outbreaks of hepatitis E have never been reported, although some authors found antibodies in some population groups (Focaccia et al. 1995, Parana et al. 1997, Souto \& Fontes 1998, Trinta et al. 2001).

Nowadays, hepatitis A can be prevented by active immunoprophylaxis and, for a better control of infection, it is necessary to investigate its current prevalence in different areas. On the other hand, further data are needed in order to evaluate the importance of HEV infection in our country. The aim of the present study was to evaluate the prevalence of $\mathrm{HAV}$ and $\mathrm{HEV}$ infections in an area where sanitary conditions were improved over the last few years.

\section{MATERIALS AND METHODS}

Calculation of sample size - The minimum sample size was estimated using the formula: $\mathrm{n}=\mathrm{Z}^{2} \mathrm{PQ} / \mathrm{d}^{2}$, considering as $\mathrm{n}=$ estimated sample size; $\mathrm{Z}=$ reduced variable, which value is 1,96 when alpha $=0,05 ; \mathrm{P}$ (estimated prevalence $)=$ probability to achieve the studied phenomenon; $\mathrm{Q}(1-\mathrm{P})=$ complement of the estimated prevalence; $\mathrm{d}$ (desired precision $)=$ margin of error. 
For anti-HAV prevalence, we assumed an alpha $=0.05$, a precision value $=3.0$ and an estimated prevalence $=80 \%$ at a confidence level $=95 \%$. For estimation of anti-HEV prevalence, precision $=1.1 \%(95 \% \mathrm{CI})$.

Population - The studied population consisted of 699 residents from Manguinhos community, located in the north area of Rio de Janeiro, Brazil, which is composed mainly by a low socio-economic group. These subjects were assisted at the Health Unit Sinval Germano Faria/ National School of Public Health (ENSP-Fiocruz), in the first semester of 1999, being submitted to any regular blood test, independent of hepatitis clinical manifestations.

The study was approved by the Ethics Committee of Fiocruz. Formal consent was given by any participant. For those under 13 years-old, informed consent was signed by a legal tutor. Blood samples were drawn from each individual and a questionnaire was administered in order to evaluate possible risk factors as contact with hepatitis virus-infected family members, household sanitary conditions, contact with contaminated water, family income, and years of education.

Serological tests - Anti-HAV antibodies (total and IgM) were determined using an "in house" enzyme immunoassay (EIA), with sensitivity and specificity similar to those of commercial kits (Vitral et al. 1991). For anti-HEV IgG detection, a commercial EIA (Abbott Laboratories Chicago, USA) was used according to the manufacturer's instructions.

Statistical analysis - Data were analyzed separately using the Epi-Info 6.04b software (Center for Diseases Control, Atlanta, USA, 1996). Univariate analysis (chisquare test, chi-square for trend and the 2-tailed Fisher exact test) was performed to check out possible correlations between the serological markers and risk factors assessed. Results were regarded as significant when $\mathrm{p}<$ 0.05 .

\section{RESULTS}

Table I shows the age-specific prevalence of anti-HAV antibodies (total and $\operatorname{IgM}$ ) in the population studied. An increase in the prevalence of anti-HAV proportionally to

\section{TABLE I}

Age-specific prevalence of anti-hepatitis A virus (HAV) antibodies (total and $\operatorname{IgM}$ ) among individuals living in the Manguinhos community, Rio de Janerio, Brazil

\begin{tabular}{crcccccc}
\hline & & \multicolumn{2}{c}{ Anti-HAV IgM } & \multicolumn{2}{c}{ Anti-HAV } \\
\cline { 7 - 8 } \cline { 7 - 7 } Age group & $\mathrm{n}$ & & Pos & $(\%)$ & & Pos & $(\%)$ \\
\hline $0-10$ & 68 & 11 & $16.2^{a}$ & & 39 & $57.4^{b}$ \\
$11-20$ & 102 & 2 & 2 & & 81 & 79.4 \\
$21-30$ & 121 & 2 & 1.7 & & 107 & 88.4 \\
$31-40$ & 87 & 0 & 0 & & 83 & 95.4 \\
$41-50$ & 102 & 4 & 4 & & 94 & 92.2 \\
$51-60$ & 94 & 2 & 2.1 & & 85 & 90.4 \\
$>60$ & 125 & 2 & 1.6 & & 119 & 95.2 \\
\hline Total & 699 & 23 & 3.3 & 608 & 87 \\
\hline
\end{tabular}

$\mathrm{n}$ : number of individuals; $a$ : anti-HAV IgM, $\mathrm{p}=0.00 ; b$ : antiHAV (2-tailed Fisher exact test) $p=0$ age was observed, with the lowest prevalence rate $(57.4 \%)$ occurring in the younger age group $(0-10$ years $)\left(\chi^{2}=\right.$ $74.40 ; \mathrm{P}=0)$. The overall prevalence of anti-HAV was $87 \%$. Almost all individuals positive for anti-HAV IgM were under 10 years old $(16.2 \%)(\mathrm{P}=0)$.

A total of 17 individuals (2.4\%) were positive for antiHEV IgG (Table II). The highest prevalence rate was ob-

TABLE II

Age-specific prevalence of anti-hepatitis E virus (HEV) IgG antibodies among individuals living in the Manguinhos community, Rio de Janeiro, Brazil

\begin{tabular}{lrrccc}
\hline & & \multicolumn{4}{c}{ Anti-HEV IgG ${ }^{a}$} \\
\cline { 3 - 6 } Age group & $\mathrm{n}$ & $\mathrm{Neg}$ & $(\%)$ & Pos & $(\%)$ \\
\hline $0-10$ & 68 & 68 & 100 & 0 & 0 \\
$11-20$ & 102 & 101 & 99 & 1 & 1 \\
$21-30$ & 121 & 120 & 99.2 & 1 & 0.8 \\
$31-40$ & 87 & 86 & 98.9 & 1 & 1.1 \\
$41-50$ & 102 & 95 & 93.1 & 7 & 6.9 \\
$51-60$ & 94 & 94 & 100 & 0 & 0 \\
$>60$ & 125 & 118 & 94.4 & 7 & 5.6 \\
\hline Total & 699 & 682 & 97.6 & 17 & 2.4 \\
\hline
\end{tabular}

$a: \mathrm{P}$ value $=0.002 ; \mathrm{n}$ : number of individuals

served in the group ranging from 41-50 years old and over 60 years $(\mathrm{P}=0.002)$.

Table III shows that the male group had a higher antiHEV IgG prevalence rate $(5.7 \%)$ than the female group $(1.3 \%)(\mathrm{P}=0.002)$.

No statistical association between HAV infection and socio-economic characteristics or housing sanitary conditions was found.

\section{TABLE III}

Prevalence of anti-hepatitis E virus (HEV) IgG, according to gender among individuals living in the Manguinhos community, Rio de Janeiro, Brazil

\begin{tabular}{lcccccc}
\hline & \multicolumn{7}{c}{ Anti-HEV IgG $^{a}$} & & \\
\cline { 2 - 5 } Sex & Neg & $(\%)$ & Pos & $(\%)$ & Total & $(\%)$ \\
\hline Male & 164 & 94.3 & 10 & 5.7 & 174 & 24.9 \\
Female & 518 & 98.7 & 7 & 1.3 & 525 & 75.1 \\
\hline Total & 682 & 97.6 & 17 & 2.4 & 699 & 100 \\
\hline
\end{tabular}

$a: \mathrm{P}$ value $=0.002$

\section{DISCUSSION}

A useful approach to understand and define the epidemiology of HAV and HEV infections is the measurement of antibodies in serum samples from specific population groups. These seroprevalence studies provide serologic and epidemiological data such as the proportion of susceptible persons, useful for defining the actual pattern of HAV and HEV epidemiology, as well as the possible changes that might be happening. This is especially true when we deal with population groups living in areas 
that are receiving improvements in general sanitation standards, since both viruses are enterically transmitted. It was this aspect that led us to choose the community of Manguinhos in Rio de Janeiro to evaluate the prevalence of HAV and HEV infection.

The total anti-HAV prevalence in this population was $87 \%$, similar to those observed in previous investigations carried out in low socio-economical status population (Sutmoller et al. 1982, Pannuti et al. 1985, Bensabath et al. 1987, Yoshida et al. 1987). However, when we analyzed the anti-HAV prevalence by age group, we noted that $42.6 \%$ of children under 10 years old were susceptible to HAV infection, an unexpected pattern in areas of high prevalence of this infection. This fact suggests a late exposure to HAV infection, probably due to improvements in sanitary conditions implemented in the last 10 years in the Manguinhos community. A retrospective investigation performed in the same community revealed that, 23 years ago, almost $100 \%$ of children under the age of 6 were exposed to HAV infection (Vitral et al. 1998a). However, HAV still circulates in this area, suggested by the presence of anti-HAV IgM in 23 individuals.

No statistical association was found between HAV infection and the risk factors here assessed.

The estimated anti-HEV prevalence of $2.4 \%$ among people living in the Manguinhos community is quite similar to the $2.1 \%$ rate observed in Sumidouro, a rural area of the State of Rio de Janeiro, where most individuals belong to a low socio- economic level (Trinta et al. 2001).

The lower anti-HAV prevalence in children under the age of 10 , found in this survey, suggest that if improvements in sanitary conditions keep occurring in this area, fewer people along the years will acquire the virus, increasing the number of susceptible persons. Thus, the possibility of future hepatitis A outbreaks in this area should not be ignored.

It is important to consider that many other regions of the country could be also suffering similar changes in HAV epidemiology due to improvements in sanitary standards (Clemens et al. 2000). Therefore, it is relevant to stimulate new studies on HAV infection prevalence and incidence in different populations of country. These data will be essential for future vaccination strategies planning.

The seroprevalence of anti-HEV IgG in subjects residing in the Manguinhos area is consistent with previous seroprevalence data reported from non-endemic areas for HEV, ranging from $1 \%$ to $5 \%$ (Dawson et al. 1992, Paul et al. 1994).

The highest anti-HEV IgG prevalence observed in the oldest age groups is according to results found in previous investigations (Balayan et al. 1996, Alvarez-Muñoz et al. 1999, Bartolini et al. 1999). The anti-HEV IgG prevalence according to sex, shows a higher rate among the male group. This finding could not be correlated with previous studies, which showed no statistical difference in the anti-HEV prevalence rate between males and females (Souto \& Fontes 1998, Alvarez-Muñoz et al. 1999, Bartolini et al. 1999).

The fact that some individuals in Manguinhos are positive for antibodies against HEV does not necessarily mean that this virus is circulating in this area. The detection of anti-HEV in non-endemic areas like Brazil is controversial (Irshad 1999, Smith 2001). It is still unknown why a low but constant presence of anti-HEV is observed in normal human populations living in non-endemic $\mathrm{HEV}$ areas (Balayan 1996). Moreover, the tests available for the detection of HEV antibodies seem to lack sensitivity and specificity to truly characterize HEV infections, impairing the determination of the true frequency of this infection in any population.

Further investigations are needed to establish the real situation of HEV infection in other regions of the country as well as the real extension of possible changes in the epidemiology of hepatitis A.

\section{ACKNOWLEDGEMENTS}

To Selma do Rosario and all the employees from the Laboratory of the Health Center Sinval Germano Faria (ENSP) involved in the collection of blood samples.

\section{REFERENCES}

Abuzwaida ARN, Sidoni M, Yoshida CFT, Schatzmayr HG 1987. Seroepidemiology of hepatitis A and B in two urban communities of Rio de Janeiro. Rev Inst Med Trop São Paulo 24: 219-223.

Alvarez-Munñoz MT, Torres J, Damasio L, Gómez A, TapiaConyer R, Muñoz O 1999. Seroepidemiology of hepatitis E virus infection in Mexican subjects 1 to 29 years of age. Arch Med Res 30: 251-254.

Arankalle VA, Tsarev SA, Chadha MS, Alling DW, Emerson SU, Banerjee K, Purcell RH 1995. Age-specific prevalence of antibodies to hepatitis A and E viruses in Pune, India 1982 and 1992. J Infect Dis 171: 447-450.

Balayan MS, Fedorova OE, Zamyatina NA, Nelga IV, Mikhailov MI, Blokhina NP, Sychev AV, Usmanov RK 1996. Hepatitis E virus (HEV) infection: prevalence of IgG class antibody to HEV in endemic versus non-endemic areas. In Y Buisson, P Coursaget, M Kane (eds), Enterically-transmitted Hepatitis Viruses, La Simarre, Joué-lès-Tours, France, p. 145-152.

Bartolini A, Bartalesi F, Roselli M, Mantella A, Arce CC, Paradisi F, Hall AJ 1999. Prevalence of antibodies against hepatitis $\mathrm{A}$ and $\mathrm{E}$ viruses among rural populations of the Chaco region, Southeastern Bolivia. Trop Med Int Health 4: 596-601.

Belyakov VD, Ovezov AO, Khozhimirzaev AK 1990. Retrospective epidemiological diagnosis of viral hepatitis non-A non-B with fecal-oral transmission. Infect Parasit Dis 2: 44-48.

Bensabath G, Hadler SC, Pereira Soares MC, Fields H, Maynard, JE 1987. Características serológicas y epidemiológicas de la hepatitis vírica aguda en la cuenca amazónica del Brasil. Bol Of Sanit Panam 103: 351-362.

CDC-Center for Diseases Control and Prevention 1987. Enterically transmitted non-A non-B hepatitis: East Africa. MMWR 36: 241-244.

Clemens SAC, Fonseca JC, Azevedo T, Cavalcanti A, Silveira TR, Castilho MC, Clemens R 2000. Hepatitis A and Hepatitis B seroprevalence in four centers in Brazil. Rev Soc Bras Med Trop 33: 1-10.

Dawson GJ, Chau KH, Cabal CM, Yarbough PO, Reyes GR, Mushahwar IK 1992. Solid-phase enzyme-linked immunobsorbent assay for hepatitis E virus $\operatorname{IgG}$ and $\mathrm{IgM}$ antibodies utilizing recombinant antigens and synthetic peptides. J Virol Methods 38: 175-186. 
Focaccia R, Sette Jr H, Conceição OJG 1995. Hepatitis E in Brazil. Lancet 346: 1165.

Irshad M 1999. Hepatitis E virus: an update on its molecular, clinical and epidemiological characteristics. Intervirology 42: 252-262.

Pannuti CS, Mendonça JS, Carvalho MJM, Oselka GW, Amato Neto N 1985. Hepatitis A antibodies in two socio-economically distinct populations of São Paulo, Brazil. Rev Inst Med Trop São Paulo 27: 162-164.

Parana R, Cotrim HP, Cortey-Boennec ML, Trepo C, Lyra L 1997. Prevalence of hepatitis $E$ virus IgG antibodies from a referral unit of liver diseases in Salvador, Brazil. Am J Med Hyg 57: 60-61.

Paul DA, Kinigge MF, Ritter A, Gutierrez R, Pilot-Matias T, Chau KH, Dawson GJ 1994. Determination of hepatitis E virus seroprevalence by using recombinant fusion protein and synthetic peptides. J Infect Dis 169: 801-806.

Psichogiou M, Hatzakis A, Tassopoulus N, Sylvans S, Hellstro'sm U, Berenesi G, Medgyesi G, Szabo I, Schlauder G, Heyermann H, Hampl H, Troonen H 1996. HEV in nonendemic regions. In Y Buisson, P Coursaget, M Kane (eds), Enterically-transmitted Hepatitis Viruses, La Simarre, Jouélès-Tours, France, p. 193-200.

Queiroz DA, Cardoso DD, Martelli CM, Martins RM, Porto SO, Azevedo MS, Borges AM, Daher RR 1995. Seroepidemiology of hepatitis A virus infection in street children of Goiânia-Goiás. Rev Soc Bras Med Trop 28: 199-203.

Schlauder GG, Frider B, Sookoian S, Castaño GC, Mushahwar IK 2000. Identification of 2 novel isolates of hepatitis $E$ virus in Argentina. J Infect Dis 182: 294-297.

Shakhgildyan IV, Khukhlovich PA, Kuzin SN 1986. Epidemiological characteristics of viral non-A non-B hepatitis with fecal-oral mode of transmission. Vopr Virusol 2: 175-179.

Smith JL 2001. A review of hepatitis E virus. J Food Prot 64: $572-586$.
Souto FJD, Fontes CJF 1998. Prevalence of IgG-class antibodies against hepatitis $E$ virus in a community of the southern Amazon: a randomized survey. Ann Trop Med Parasitol 92: 623-625.

Sutmoller F, Gaspar AMC, Cynamon SE, Richa N, Mercadante LAC, Schatzmayr HE 1982. A water-borne hepatitis A outbreak in Rio de Janeiro. Mem Inst Oswaldo Cruz 77: 917.

Trinta KS, Liberto MI, de Paula VS, Yoshida CF, Gaspar AM 2001. Hepatitis E virus infection in selected Brazilian population. Mem Inst Oswaldo Cruz 96: 25-29.

Velazquez O, Stetler HC, Avila C, Ornelas G, Alvarez C, Hadler SC, Bradley DW, Sepulveda J 1990. Epidemic transmission of enterically transmitted non-A, non-B hepatitis in Mexico, 1986-1987. JAMA 263: 3281-3285.

Vitral CL, Gaspar AMC, Yoshida CFT 1991. Two competitive enzyme immunoassays for the detection of IgG class antibodies to hepatitis A antigen. Rev Soc Bras Med Trop 24: 79-85.

Vitral CL, Yoshida CFT, Lemos ERS, Teixeira CS, Gaspar AMC 1998a. Age-specific prevalence of antibodies to hepatitis A in children and adolescents from Rio de Janeiro, Brazil, 1978 and 1995. Relationship of prevalence to environmental factors. Mem Inst Oswaldo Cruz 93: 1-5.

Vitral CL, Yoshida CFT, Teixeira CS, Gaspar AMC 1998b. Seroprevalence of hepatitis A in health care students from a public university of Rio de Janeiro, Brazil. Rev Microbiol 29: 149-151.

Yoshida CFT, Nogueira RMR, Mercadante LAC, Pinhão AT, Schatzmayr HG 1987. Seroepidemiological survey of hepatitis A and B cytomegalovirus and herpes simplex type 2 in prime blood donors from Rio de Janeiro, Brazil. Rev Microbiol 18: 5-11.

Zuang H 1992. Hepatitis E and strategies for its control. In YM Wen, ZY Xu, JL Melnick (eds), Viral Hepatitis in China: Problems and Control Strategies, Karger, Basel. 